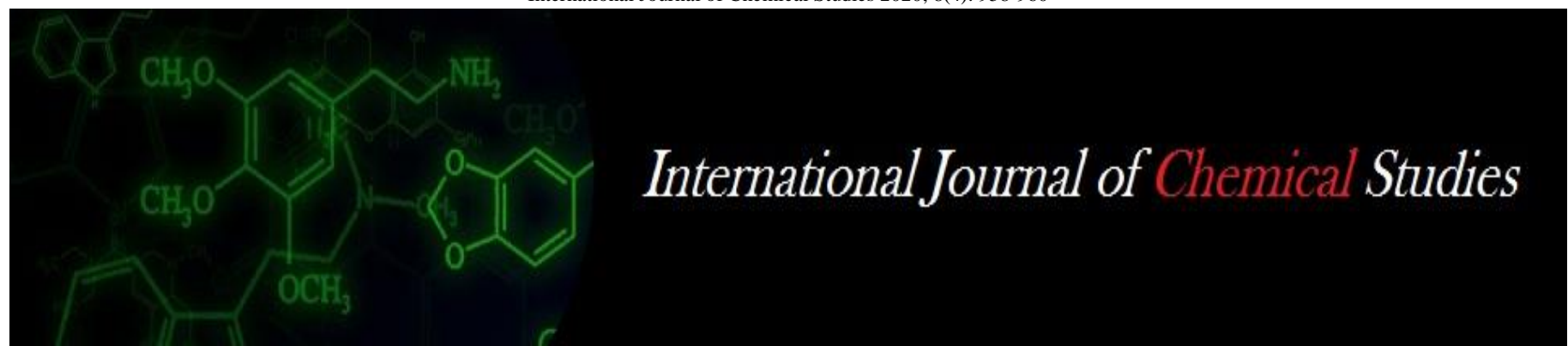

P-ISSN: 2349-8528

E-ISSN: 2321-4902

www.chemijournal.com

IJCS 2020; 8(4): 958-960

(C) 2020 IJCS

Received: 01-05-2020

Accepted: 04-06-2020

\section{SS Shilewant}

Department of Soil Science and Agril. Chemistry, College of Agriculture, VNMKV, Parbhani, Maharashtra, India

\section{VD Patil}

Department of Soil Science and Agril. Chemistry, College of Agriculture, VNMKV, Parbhani,

Maharashtra, India

\section{SL Waikar}

Department of Soil Science and Agril. Chemistry, College of Agriculture, VNMKV, Parbhani, Maharashtra, India

\section{HK Kausadikar}

Department of Soil Science and Agril. Chemistry, College of Agriculture, VNMKV, Parbhani, Maharashtra, India

Corresponding Author: SS Shilewant

Department of Soil Science and Agril. Chemistry, College of Agriculture, VNMKV, Parbhani, Maharashtra, India

\section{Effect of soil and foliar feeding of nutrients through organic and inorganic sources on yield and quality of sweet orange (Citrus Sinensis L. Osbeck)}

\author{
SS Shilewant, VD Patil, SL Waikar and HK Kausadikar
}

DOI: https://doi.org/10.22271/chemi.2020.v8.i4g.9724

\section{Abstract}

A field experiment was conducted during 2014-15 at Water management farm, Vasantrao Naik Marathwada Krishi Vidyapeeth, Parbhani on 10 year old sweet orange orchard to assess the effect of soil and foliar feeding of nutrient application through organic and inorganic sources on yield and quality of sweet orange (Citrus sinensis L. osbeck). The study indicates that treatment $\mathrm{T}_{12}$ with application of NPK in 8 splits with drip irrigation + vermicompost @ 3 tonne ha $^{-1}$ and biofertilizers i.e Azotobacter and PSB @ $2000 \mathrm{ml}$ per ha and trichoderma @ $1 \mathrm{~kg} \mathrm{ha}^{-1}+8$ spraying of $\mathrm{Zn}(0.5 \%), \mathrm{Fe}(0.5 \%)$ and $\mathrm{B}(0.2 \%)$ found to be most effective to producing number of fruits, weight of fruits, and yield and fruit quality parameters like ascorbic acid, TSS, acidity and total sugar percentage.

Keywords: Sweet orange, yield, ascorbic acid, TSS etc.

\section{Introduction}

In India 2013-14 citrus fruit are grown in an area of 1078 thousand ha, with a production of 11147.1 thousand million tones and productivity 10.3 (Mt ha $\left.{ }^{-1}\right)$. In Maharashtra 2013-14 sweet orange fruit was cultivated on an area of 95 thousand ha, with a production of 712.5 thousand million tones and productivity $7.5\left(\mathrm{Mt} \mathrm{ha}^{-1}\right)$. Marathwada is a mother of sweet orange (Citrus sinesis osbec.) which is concentrated in Aurangabad, Jalna, Parbhani and Nanded districts of south part of Maharashtra. The average productivity of 'Mosambi' i.e. sweet orange is 14.9 t/ha which comparatively lower. One of the main reasons for low sweet orange orchard productivity in the soils of Marathwada region is due to multiple nutrient deficiencies. The soils of this region are mostly derived from basaltic parent material and are commonly deficient in multiple nutrients, including N, P, Fe and Zn (Srivastava and Singh, 2004 and Patil, 1997) ${ }^{[11,6]}$.

Soil reaction may be a problem in micronutrient deficiencies, necessitating application of foliar micronutrient sprays. In recent years, much importance is given for correction of nutritional disorders through foliar sprays of nutrients. Works carried out from different parts of country appear to be inadequate. Therefore, evaluation of the effect of soil and foliar treatments of micronutrients in sweet orange on quality and yield of fruits is important. (Kausadikar, 2005) ${ }^{[2]}$.

To stabilize fruit production and quality, it is necessary to supply adequate irrigation in the dry season, and proper drainage during the wet season. It is important to provide the right amount of water and fertilizers at different growth stages not only enhances the growth of citrus trees, but also improves yield and fruit quality (Shirgure et al., 2000a) ${ }^{[9]}$.

\section{Materials and Methods}

The field experiments were carried out using sweet orange orchard in Ambia bahar at Water management farm, Vasantrao Naik Marathwada Krishi Vidyapeeth, Parbhani, during years 2014-15. The experiment was laid out in Randomized Block Design comprising thirteen (13) treatments, $\mathrm{T}_{1}-\mathrm{RDF}+4$ spraying of $(\mathrm{Zn}+\mathrm{B}+\mathrm{Fe}), \mathrm{T}_{2}-\mathrm{RDF}+6$ spraying of $(\mathrm{Zn}+\mathrm{B}+\mathrm{Fe}), \mathrm{T}_{3}-$ $\mathrm{RDF}+8$ spraying of $(\mathrm{Zn}+\mathrm{B}+\mathrm{Fe}), \mathrm{T}_{4}-\mathrm{RDF}+$ Vermicompost + biofertilizer +4 spraying of $(\mathrm{Zn}+\mathrm{B}+\mathrm{Fe})$, 
$\mathrm{T}_{5}$ - RDF+ Vermicompost+ biofertilizer +6 spraying of $(\mathrm{Zn}+\mathrm{B}+\mathrm{Fe}), \mathrm{T}_{6}-\mathrm{RDF}+$ Vermicompost+ biofertilizer +8 spraying of $(\mathrm{Zn}+\mathrm{B}+\mathrm{Fe}), \mathrm{T}_{7^{-}}$Vermicompost+ biofertilizer +4 spraying of $(\mathrm{Zn}+\mathrm{B}+\mathrm{Fe}), \mathrm{T}_{8}-$ Vermicompost+ biofertilizer +6 spraying of $(\mathrm{Zn}+\mathrm{B}+\mathrm{Fe}), \mathrm{T}_{9}-$ Vermicompost + biofertilizer +8 spraying of $(\mathrm{Zn}+\mathrm{B}+\mathrm{Fe}), \mathrm{T}_{10^{-}} \mathrm{RDF}$ through fertigation + Vermicompost+ biofertilizer +4 spraying of $(\mathrm{Zn}+\mathrm{B}+\mathrm{Fe}), \mathrm{T}_{11^{-}}$ RDF through fertigation + Vermicompost+ biofertilizer +6 spraying of $(\mathrm{Zn}+\mathrm{B}+\mathrm{Fe}), \mathrm{T}_{12^{-}} \mathrm{RDF}$ through fertigation + Vermicompost + biofertilizer +8 spraying of $(\mathrm{Zn}+\mathrm{B}+\mathrm{Fe})$ and $\mathrm{T}_{13^{-}}$control, replicated four times in sweet orange orchard. Recommended fertilizer dose NPK is 800:400:400 gm/tree, As per the treatment half dose of nitrogen and full dose of phosphorus, potassium were applied in the form of Urea, Single Super phosphate and Murate of potash respectively near the feeding root zone and mixed thoroughly in soil after release of water stress. Remaining half dose of nitrogen was given one to one and half month thereafter when fruit set. $\mathrm{Zn}+\mathrm{B}+\mathrm{Fe}$ : [Chelated zinc $(0.5 \%)+$ Borax $(0.2 \%)+$ Chelated $\mathrm{Fe}(0.5 \%)]$ applied in foliar spraying, and Vermicompost (3tonne/ha), Azotobactor (800ml/acre), PSB (800ml/acre), and Trichoderma $(1 \mathrm{~kg} / \mathrm{ha})$ were applied.

Harvesting was carried out at once. Yield in respects of number of fruit per tree, weight of fruit $(\mathrm{kg} /$ tree) and yield $(\mathrm{kg}$ $\mathrm{ha}^{-1}$ ) was recorded. Observations on fruit size, fruit weight were based on random five fruit samples. Fruit quality parameters, viz., Total soluble solids were recorded with the help of hand refractometer (Erma Tokkyo A 300C),total sugars (reducing and non reducing sugar), acidity with titrable acidity and ascorbic acid with titrimitic method were determined as per standard procedures given by AOAC (1965).

\section{Results and Discussion}

Effect of different nutrient management practices on yield parameters in sweet orange: The data on number of fruits per tree, weight of fruit, volume of fruit and yield per tree presented in Table 1.

\section{Yield Attributes of sweet orange}

The data pertaining to number of fruits per tree was observed statistically significant by the different management practices are given in Table 1. The number of fruits per tree increased from 48.25 to 206.50 at harvest. The treatment $\mathrm{T}_{12}$ was RDF plus vermicompost plus biofertilizers along with 8 spraying of zinc, boron and iron was at par with treatment $T_{11}$ which is RDF plus vermicompost plus biofertilizers along with 6 spraying of zinc, boron and iron and significantly superior over rest of treatments.

The production of more number of fruits in the treatments of application of bio-fertilizers with chemical fertilizers at different combination could be a result of the improvement in soil physical and chemical properties which in turn provided required nutrition for the conversion of flowers to fruits resulting in higher fruit set ultimately, increasing the number of fruits per tree. The data presented in Table 1, the maximum weight of fruit $225.57 \mathrm{~g}$ in treatment $\mathrm{T}_{6}$ and minimum weight of fruit $170.95 \mathrm{~g}$ in treatment $\mathrm{T}_{13}$ were recorded. The perusal of the data presented in the Table 1 shows the different combinations of organic and inorganic fertilizers treatments significantly improved the yield. The fruit yield was increased from 21.27 to $46.15 \mathrm{~kg} /$ tree. Treatment $\mathrm{T}_{12}$ was application of RDF through fertigation plus vermicompost plus biofertilizers with 8 numbers of spraying of zinc, boron and iron found significantly superior over rest of the treatment except $\mathrm{T}_{10}, \mathrm{~T}_{8}$ and $\mathrm{T}_{4}$.

Table 1: Effect of different nutrient management practices on yield attributes of sweet orange

\begin{tabular}{|c|c|c|c|c|c|}
\hline $\begin{array}{c}\text { Treat. } \\
\text { No. } \\
\end{array}$ & Treatment & \begin{tabular}{|c|}
$\begin{array}{c}\text { No. of fruits / } \\
\text { tree }\end{array}$ \\
\end{tabular} & $\begin{array}{c}\text { Wt. of } \\
\text { fruits (g) }\end{array}$ & \begin{tabular}{|c|}
$\begin{array}{c}\text { Yield kg } \\
\text { tree }^{-1}\end{array}$ \\
\end{tabular} & \begin{tabular}{|c|}
$\begin{array}{c}\text { Vol. of fruit } \\
\left(\mathrm{cm}^{3}\right)\end{array}$ \\
\end{tabular} \\
\hline $\mathrm{T}_{1}$ & $\mathrm{RDF}+4$ spraying of $(\mathrm{Zn}+\mathrm{B}+\mathrm{Fe})$ & 105.50 & 196.15 & 21.24 & 200.00 \\
\hline $\mathrm{T}_{2}$ & $\mathrm{RDF}+6$ spraying of $(\mathrm{Zn}+\mathrm{B}+\mathrm{Fe})$ & 119.25 & 201.35 & 21.27 & 188.75 \\
\hline $\mathrm{T}_{3}$ & $\mathrm{RDF}+8$ spraying of $(\mathrm{Zn}+\mathrm{B}+\mathrm{Fe})$ & 162.25 & 214.25 & 31.83 & 186.00 \\
\hline $\mathrm{T}_{4}$ & $\mathrm{RDF}+$ Vermicompost+ biofertilizers +4 spraying of $(\mathrm{Zn}+\mathrm{B}+\mathrm{Fe})$ & 149.75 & 202.40 & 33.79 & 192.00 \\
\hline $\mathrm{T}_{5}$ & RDF+ Vermicompost+ biofertilizers +6 spraying of $(\mathrm{Zn}+\mathrm{B}+\mathrm{Fe})$ & 128.00 & 202.85 & 25.97 & 217.00 \\
\hline $\mathrm{T}_{6}$ & $\mathrm{RDF}+$ Vermicompost + biofertilizers +8 spraying of $(\mathrm{Zn}+\mathrm{B}+\mathrm{Fe})$ & 143.00 & 225.57 & 28.94 & K8189.50 \\
\hline $\mathrm{T}_{7}$ & Vermicompost + biofertilizers +4 spraying of $(\mathrm{Zn}+\mathrm{B}+\mathrm{Fe})$ & 133.25 & 187.58 & 21.25 & 177.75 \\
\hline $\mathrm{T}_{8}$ & Vermicompost + biofertilizers +6 spraying of $(\mathrm{Zn}+\mathrm{B}+\mathrm{Fe})$ & 145.00 & 199.15 & 34.92 & 188.75 \\
\hline $\mathrm{T}_{9}$ & Vermicompost + biofertilizers +8 spraying of $(\mathrm{Zn}+\mathrm{B}+\mathrm{Fe})$ & 172.25 & 202.74 & 28.88 & 189.50 \\
\hline $\mathrm{T}_{10}$ & RDF through fertigation + Vermicompost + biofertilizers +4 spraying of $(\mathrm{Zn}+\mathrm{B}+\mathrm{Fe})$ & 164.25 & 220.85 & 36.27 & 219.00 \\
\hline $\mathrm{T}_{11}$ & RDF through fertigation + Vermicompost + biofertilizers +6 spraying of $(\mathrm{Zn}+\mathrm{B}+\mathrm{Fe})$ & 172.50 & 215.50 & 31.17 & 204.25 \\
\hline $\mathrm{T}_{12}$ & RDF through fertigation + Vermicompost + biofertilizers +8 spraying of $(\mathrm{Zn}+\mathrm{B}+\mathrm{Fe})$ & 206.50 & 223.50 & 46.15 & 222.50 \\
\hline $\mathrm{T}_{13}$ & Control & 48.25 & 170.95 & 21.27 & 151.00 \\
\hline & S.Em. \pm & 19.25 & 9.35 & 4.70 & 6.22 \\
\hline & C.D. at 5\% & 55.78 & 27.11 & 13.63 & 18.33 \\
\hline & Mean & 142.29 & 204.83 & 29.46 & 194.31 \\
\hline
\end{tabular}

Effect of different nutrient management practices on volume of fruits $\left(\mathrm{cm}^{3}\right)$ per tree in sweet orange. The data regarding effect of organic and inorganic fertilizers on volume of fruits are presented in Table.1 The application of organic and inorganic fertilizers significantly influenced the volume of fruits. The volume of fruits were ranged from 151.00 to $222.50 \mathrm{~cm}^{3}$, the results on similar lines were also reported by
Patel et al. (2012) ${ }^{[7]}$ and (Verma and Rao, 2013) ${ }^{[12]}$ who studied that increased in fruit yield and its parameters may be due to increased in the number of leaves which worked as an efficient photosynthesis structure and produce high amount of carbohydrates in the plant system. These findings are in agreement with the findings of (Nazir et al.2015) ${ }^{[5]}$. 
Effect of different nutrient management practices on quality parameters in sweet orange.

Table 2: Effect of different nutrient management practices on quality parameters of sweet orange.

\begin{tabular}{|c|c|c|c|c|c|}
\hline \begin{tabular}{|c|} 
Treat. \\
No. \\
\end{tabular} & Treatment & $\begin{array}{c}\text { Ascorbic acid } \\
(\mathrm{mg} / 100 \mathrm{ml} \text { juice })\end{array}$ & $\begin{array}{c}\text { TSS } \\
\left(\text { Brix }^{0}\right)\end{array}$ & $\begin{array}{c}\text { Acidity } \\
(\%)\end{array}$ & $\begin{array}{c}\text { Total sugars } \\
(\%)\end{array}$ \\
\hline $\mathrm{T}_{1}$ & $\mathrm{RDF}+4$ spraying of $(\mathrm{Zn}+\mathrm{B}+\mathrm{Fe})$ & 51.24 & 9.20 & 0.81 & 7.62 \\
\hline $\mathrm{T}_{2}$ & $\mathrm{RDF}+6$ spraying of $(\mathrm{Zn}+\mathrm{B}+\mathrm{Fe})$ & 54.72 & 10.10 & 0.78 & 8.01 \\
\hline $\mathrm{T}_{3}$ & $\mathrm{RDF}+8$ spraying of $(\mathrm{Zn}+\mathrm{B}+\mathrm{Fe})$ & 54.21 & 9.35 & 0.76 & 7.71 \\
\hline $\mathrm{T}_{4}$ & $\mathrm{RDF}+$ Vermicompost+ biofertilizers +4 spraying of $(\mathrm{Zn}+\mathrm{B}+\mathrm{Fe})$ & 55.64 & 9.90 & 0.79 & 7.96 \\
\hline $\mathrm{T}_{5}$ & RDF+ Vermicompost+ biofertilizers +6 spraying of $(\mathrm{Zn}+\mathrm{B}+\mathrm{Fe})$ & 53.21 & 10.20 & 0.78 & 8.18 \\
\hline $\mathrm{T}_{6}$ & RDF+ Vermicompost + biofertilizers +8 spraying of $(\mathrm{Zn}+\mathrm{B}+\mathrm{Fe})$ & 57.22 & 10.40 & 0.75 & 8.2 \\
\hline $\mathrm{T}_{7}$ & Vermicompost + biofertilizers +4 spraying of $(\mathrm{Zn}+\mathrm{B}+\mathrm{Fe})$ & 55.32 & 9.80 & 0.74 & 7.89 \\
\hline $\mathrm{T}_{8}$ & Vermicompost + biofertilizers +6 spraying of $(\mathrm{Zn}+\mathrm{B}+\mathrm{Fe})$ & 56.62 & 9.60 & 0.72 & 7.91 \\
\hline $\mathrm{T}_{9}$ & Vermicompost + biofertilizers +8 spraying of $(\mathrm{Zn}+\mathrm{B}+\mathrm{Fe})$ & 54.04 & 10.15 & 0.74 & 7.93 \\
\hline $\mathrm{T}_{10}$ & RDF through fertigation + Vermicompost + biofertilizers +4 spraying of $(\mathrm{Zn}+\mathrm{B}+\mathrm{Fe})$ & 56.67 & 10.25 & 0.79 & 8.12 \\
\hline $\mathrm{T}_{11}$ & RDF through fertigation + Vermicompost + biofertilizers +6 spraying of $(\mathrm{Zn}+\mathrm{B}+\mathrm{Fe})$ & 58.76 & 10.30 & 0.75 & 8.22 \\
\hline $\mathrm{T}_{12}$ & RDF through fertigation + Vermicompost + biofertilizers +8 spraying of $(\mathrm{Zn}+\mathrm{B}+\mathrm{Fe})$ & 62.16 & 10.60 & 0.74 & 8.31 \\
\hline \multirow[t]{4}{*}{$\mathrm{T}_{13}$} & Control & 52.04 & 9.10 & 0.73 & 7.05 \\
\hline & S.Em. \pm & 1.27 & 0.14 & 0.007 & 0.06 \\
\hline & C.D. at $5 \%$ & 3.69 & 0.40 & NS & 0.17 \\
\hline & Mean & 55.53 & 9.92 & 0.76 & 7.93 \\
\hline
\end{tabular}

The data presented in Table 2 revealed that ascorbic acid, TSS content and Total sugar percentage was significantly highest in treatment $T_{12}$ followed by $T_{11}$ and $T_{6}$ treatments. Treatments with combine application of inorganic and organic sources recorded highest ascorbic acid while inorganic fertilizers recorded lower ascorbic acid content; it is lowest with the application of RDF with 4 numbers of spraying of $\mathrm{Zn}, \mathrm{Fe}$ and $\mathrm{B}$. These results are in line with the findings of Seshadri and Madhavi (2001) ${ }^{[8]}$ in sweet orange. The acidity percentage was ranged from 0.72 to 0.81 . (Table 2) The acidity of fruits was recorded lowest in treatments involving individual application of organic manures compared to inorganic fertilizer treatments. Marathe (2005) [3] reported increase in acidity of fruit juice of sweet orange with increasing dose of $\mathrm{N}, \mathrm{P}$ and $\mathrm{K}$ application reduced acidity. Improved fruit quality may be attributed to better vegetative growth of the treated plants, which resulted in higher quantities of photosynthates (starch, carbohydrate etc.) and translocation to the fruits thus increasing the contents of various fruits quality parameters (Dutta et al. 2014 and Mir et al. 2015) ${ }^{[1,4]}$.

\section{Conclusion}

There was improvement in yield, yield attributes quality parameters of sweet orange due to application of RDF with vermicompost and biofertilizers (Azotobacter, PSB and trichoderma) with or without drip irrigation along with $\mathrm{Zn}, \mathrm{Fe}$ and $\mathrm{B}$ micronutrients spraying with an interval of 1 and 1.5 month.

\section{References}

1. Dutta P, Kundu S, Bauri FK, Talang H, Majumder D. Effect of bio-fertilizers on physico-chemical qualities and leaf mineral composition of guava grown in alluvial zone of west Bengal. J Crop and weed. 2014; 10(2):268-271.

2. Kausadikar HK. Studies on nutritional disorders in sweet orange and their response to multi- micronutrient application. Ph. D. Thesis MAU, Parbhani Maharashtra India, 2005.

3. Marathe RA. Effect of integrated nutrient management on soil properties, yield and quality of sweet orange (Citrus sinensis osbeck) grown on vertisol. Ph.D. Thesis. Dr. Panjabrao Deshmukh Krishi Vidyapeeth, Akola, M.S., India, 2005.
4. Mir M, Sharma S, Kumar P. Nutrient dynamics: effect on cropping behavior, nutrient profile and quality attributes of pomegranate (Punica granatum L.) under rainfed agroclimatic conditions. J Plant nutrition. 2015; 38:83-95.

5. Nazir N, Kumar A, Khalil A, Bandey SA. Effect of integrated organic nutrient management on fruit yield and quality of strawberry cv. Senga sengana. Internat. J fark2m Sci. 2015; 5(2):83-89.

6. Patil VD. Assessment of chemical and bio-chemical indices for diagnosing zinc deficiency and soil associated factors of citrus (Citrus sinensis osbeck) nutrition. Ph. D. Thesis MAU, Parbhani Maharashtra India, 1997.

7. Patel KM, Patel HC, Patel KA, Chauhan VB, Patel JS. Effect of manures and fertilizers on growth and fruit yield of acid lime cv. Kagzi (Citrus aurentifolia Swingle). Asian J Hort. 2012; 7(2):481-483.

8. Seshadri KV, M Madhavi. Effect of organic and inorganic manuring on twenty year old seedling of sweet orange (Citrus sinensis (L.) Oosbeck) cv. Sathugudi. National Seminar on "Changing Scenario in the Production Systems of Horticultural Crops" Aug. 28 30, TNAU, Coimbatore, India, 2001, 122.

9. Shirgure PS, Srivastava AK, Singh S. Water management in citrus - A review. Agri. Rev. 2000a; 21(4):223-230.

10. Srivastava AK, Singh Shyam. Nutrient constraints analysis of healthy and declining sweet orange orchards of Marathwada. Abs. $4^{\text {th }}$ Agril.Sci. Cong. pp. 220. Feb. 21-24, Jaipur, India, 1999.

11. Srivastava AK, S Singh. Soil and plant nutritional constraints contributing to citrus decline in Marathawada region, India. Communications in Soil Science \& Plant Analysis. 2004; 35:2537-2550.

12. Verma J, Rao VK. Impact of INM on soil properties, plant growth and yield parameters of strawberry cv. Chandler. J hill Agric. 2013; 4(2):61-67. 